\title{
Peritoneal Dialysis for Potential Kidney Transplant Recipients: Pride or Prejudice?
}

\author{
Luca Nardelli ${ }^{1}{ }^{\circledR}$, Antonio Scalamogna ${ }^{1}$, Piergiorgio Messa ${ }^{1,2}$, Maurizio Gallieni ${ }^{3,4}{ }^{\circledR}$, Roberto Cacciola ${ }^{5}($, \\ Federica Tripodi ${ }^{1}$, Giuseppe Castellano ${ }^{1,2}$ and Evaldo Favi ${ }^{2,6, *(\mathbb{B})}$
}

1 Nephrology, Dialysis and Transplantation, Fondazione IRCCS Ca' Granda Ospedale Maggiore Policlinico, 20122 Milan, Italy; luca.nardelli@unimi.it (L.N.); antonio.scalamogna@policlinico.mi.it (A.S.); piergiorgio.messa@unimi.it (P.M.); fedetr89@gmail.com (F.T.); giuseppe.castellano@unimi.it (G.C.)

2 Department of Clinical Sciences and Community Health, University of Milan, 20122 Milan, Italy

3 Department of Biomedical and Clinical Sciences, Università di Milano, 20157 Milan, Italy; maurizio.gallieni@unimi.it

4 Nephrology and Dialysis Unit, ASST Fatebenefratelli Sacco, 20157 Milan, Italy

5 Department of Surgical Sciences, Università di Tor Vergata, 00133 Rome, Italy; rc.1968@icloud.com

6 Kidney Transplantation, Fondazione IRCCS Ca' Granda Ospedale Maggiore Policlinico, 20122 Milan, Italy

* Correspondence: evaldofavi@gmail.com; Tel.: +39-3666036167

check for

updates

Citation: Nardelli, L.; Scalamogna,

A.; Messa, P.; Gallieni, M.; Cacciola,

R.; Tripodi, F.; Castellano, G.; Favi, E.

Peritoneal Dialysis for Potential

Kidney Transplant Recipients: Pride

or Prejudice?. Medicina 2022, 58, 214.

https://doi.org/10.3390/

medicina58020214

Academic Editor: Wisit

Cheungpasitporn

Received: 15 December 2021

Accepted: 29 January 2022

Published: 1 February 2022

Publisher's Note: MDPI stays neutral with regard to jurisdictional claims in published maps and institutional affiliations.

Copyright: () 2022 by the authors. Licensee MDPI, Basel, Switzerland. This article is an open access article distributed under the terms and conditions of the Creative Commons Attribution (CC BY) license (https:// creativecommons.org/licenses/by/ $4.0 /)$.

\begin{abstract}
Kidney transplantation (KT) is recognized as the gold-standard of treatment for patients with end-stage renal disease. Additionally, it has been demonstrated that receiving a pre-emptive KT ensures the best recipient and graft survivals. However, due to an overwhelming discrepancy between the organs available and the patients on the transplant waiting list, the vast majority of transplant candidates require prolonged periods of dialysis before being transplanted. For many years, peritoneal dialysis (PD) and hemodialysis (HD) have been considered competitive renal replacement therapies (RRT). This dualistic vision has recently been questioned by evidence suggesting that an individualized and flexible approach may be more appropriate. In fact, tailored and cleverly planned changes between different RRT modalities, according to the patient's needs and characteristics, are often needed in order to achieve the best results. While home HD is still under scrutiny in this particular setting, current data seems to favor the use of PD over in-center HD in patients awaiting a KT. In this specific population, the demonstrated advantages of PD are superior quality of life, longer preservation of residual renal function, lower incidence of delayed graft function, better recipient survival, and reduced cost.
\end{abstract}

Keywords: kidney transplantation; peritoneal dialysis; hemodialysis; patient survival; allograft survival; renal function; delayed graft function; quality of life; outcomes

\section{Introduction}

Kidney transplantation (KT) represents the "Gold-Standard" of treatment for patients with end-stage renal disease (ESRD) [1-5]. Ideally, a pre-emptive strategy should be adopted to ensure the best results [6-9]. However, due to the scarcity of donors, the vast majority of transplant candidates require prolonged periods of renal replacement therapy (RRT) before receiving a suitable organ [10,11].

For many years, in-center hemodialysis (ICHD) has represented the only option available [12,13]. In the 1980s, the introduction of peritoneal dialysis (PD) into clinical practice $[14,15]$, raised the question of which RRT should have been preferred in potential KT recipients [16-19]. Main concerns regarding the routinary use of PD in this particular population were the presence of peritoneal scarring due to previous abdominal surgery, the risk of peri-operative peritonitis [20,21] or exit-site/tunnel infections [20,22], the higher susceptibility to post-transplant diabetes mellitus $[23,24]$, the possible development of 
encapsulating peritoneal sclerosis $[25,26]$, and the perceived increase in graft thrombosis [23,27-29] and acute rejection rates [16,30].

Even though several studies have demonstrated that PD does not exert any negative impact on transplant-related outcomes [31-33], some clinicians remain reluctant to propose this dialysis option to patients on the transplant waiting list (TWL) [34,35]. Such an attitude is certainly questionable since ICHD, home HD (HHD), and PD should not be regarded as competitive modalities, rather as complementary strategies before [36-39] and after transplant [40-43]. Indeed, RRT must be tailored to the specific needs and characteristics of the patient, taking into account the time-dependent variability of these parameters and local facilities [44]. Carefully planned changes between different dialysis techniques can also be considered, in particular circumstances $[45,46]$.

While HHD is still under scrutiny in this particular setting [47-50], there is now evidence suggesting that in patients awaiting a KT, PD may be better than ICHD in terms of quality of life (QoL), residual renal function (RRF) preservation, the incidence of delayed graft function (DGF), graft survival, mortality, and cost.

In the present narrative review, we discuss how the role of PD has changed over time, focusing on the management of patients on the TWL.

\section{Patient Survival on Renal Replacement Therapy}

Patients with ESRD suffer a higher prevalence of cardiovascular disease (CVD), greater incidence of major cardiovascular events, and increased all-cause mortality than the general population [10,51]. These factors can significantly influence the risk of suspension from the TWL and jeopardize recipient and graft survivals after transplant [52].

In a seminal study including 398940 individuals who had started RRT between 1995 and 2000, [53] found that, excluding older diabetic subjects, the adjusted mortality rates on ICHD and PD were substantially similar. Actually, patient survival in both groups varied according to specific clinical characteristics, such as the underlying cause of renal failure, age, and comorbidity [53]. In the same period, a Danish registry analysis, performed on 4568 ICHD and 2443 PD patients, showed that PD could provide a survival advantage over ICHD during the first two years of RRT [54]. Evaluating a Canadian cohort of dialysis patients, Fenton and colleagues also observed that, in young and non-diabetic individuals, PD was associated with higher short-term survival rates than ICHD [55]. A few years later, data collected from the Dutch End-Stage Renal Disease Registry confirmed that patient survival on PD and ICHD was primarily influenced by the presence of diabetic nephropathy and by the age at the time of RRT initiation. In younger ( $<50$ years) nondiabetic subjects, PD ensured a better overall survival than ICHD. However, the benefit was lost in older ( $>60$ years) or diabetic individuals [56]. In line with previous studies, a more recent comparison between 6337 pairs of ICHD and PD patients, matched using the propensity score method, showed that individuals starting on PD had an $8 \%$ reduction in the overall risk of death compared to those starting on ICHD [57].

Over the last two decades, we have witnessed a progressive improvement of dialysisrelated outcomes, particularly with home-based modalities [38,49,58,59]. As shown by the US Renal Data System (USRDS) Annual Reports in a population of 650000 subjects on RRT, prevalent patients receiving PD had their survival probabilities doubled from 1996 to 2002 [60] and their adjusted all-cause mortality rates decreased from 164.2 to 131.5 per thousand patient-years from 2009 to 2018 [10]. Such remarkable improvement was evident also among older patients with hypertension or diabetes [10].

\section{Post-Transplant Recipient and Allograft Survivals}

It is demonstrated that KT provides superior life expectancy [61-63] and QoL [64-66] than dialysis. Nonetheless, returning to dialysis after a failed transplant entails a greater risk of death than starting RRT for the first time $[11,40,43,67,68]$. Therefore, preserving graft function as much as possible is vital for long-term patient survival. 
Several studies have investigated the impact of pre-transplant dialysis modality on post-transplant outcomes, with mixed results. In the early 1990s, a retrospective analysis on 500 first deceased-donor KT showed no differences between ICHD and PD in short-term patient ( $88 \%$ vs $87 \%$ ) and graft survival (67\% vs 66\%) rates [69]. Comparable early patient and graft survivals were also reported in other small series from Ohio State University [70], CHRU Lille [71], and University of Glasgow [72], as well as by a retrospective Medicare database analysis on 22776 transplant recipients [73]. On the contrary, using the USRDS, Goldfarb-Rumyantzev et al. found that pre-transplant PD was associated with a 3\% reduction in the risk of graft failure $(p<0.05)$ and a $6 \%$ reduction in the risk of death $(p<0.001)$ compared to ICHD [74]. Most of the studies published in the following years and focusing on short- or mid-term outcomes, failed to demonstrate the superiority of an RRT technique over the other ones [75-79]. However, extending the post-transplant follow-up to ten years, Lopez-Oliva et al. managed to show that, despite similar graft survival probabilities ( $\mathrm{HR}=0.68,0.41-1.10 ; p=0.12)$, recipients previously treated with PD had higher chances of survival than those on ICHD (HR $=2.62,1.01-6.8 ; p=0.04)$ [80]. A better recipient survival (with an equivalent transplant failure rate) was also reported by Schwenger et al. using the large (60008 subjects) database of the International Collaborative Transplant Study Group. On multivariate Cox regression analysis, pre-transplant PD (11664 patients) was associated with a 10\% reduction in all-cause mortality $(p=0.014)$ compared to ICHD (45651 patients), with a similar death-censored graft survival rate $(p=0.39)$. Such discrepancy in overall mortality was primarily attributed to a lower incidence of cardiovascular death with preserved graft function observed among PD patients who had received an expanded criteria kidney [81]. Evaluating the Scientific Registry of Transplant Recipients, Molnar et al. found that patients treated with PD before transplant had a lower (21.9/1000 patient-year, 95\% CI 18.1-26.5) crude all-cause mortality than recipients previously treated with ICHD (32.8/1000 patient-year, 95\% CI 30.8-35.0). More precisely, PD was associated with $43 \%$ lower adjusted all-cause mortality, $66 \%$ lower adjusted cardiovascular death, and 17\% lower unadjusted death-censored graft failure [82]. A recent meta-analysis, including a total of 16 studies published between 1980 and 2014, calculated a pooled adjusted mortality risk ratio of 0.89 (95\% CI 0.82-0.97; $p=0.006$ ) in favor of pre-transplant PD, with marginal differences in graft survival (pooled adjusted risk ratio $0.97(95 \%$ CI $0.92-1.01 ; p=0.16)$ [32]. Analyzing the National Health Insurance (NHI) database, a nationwide cohort study from Taiwan also showed that, in the multivariate analysis, after adjustment for age, sex, time on RRT, and primary renal disease, pre-transplant HD increased the risk of premature transplant loss compared to PD (HR $1.38, p<0.05)$. Furthermore, higher incidences of new-onset CVD and specific infectious complications such as tuberculosis and hepatitis $C$ were recorded [83].

It has been argued that the differences in pre- and post-transplant outcomes between PD and ICHD are due to the fact that patients on PD are generally healthier than their ICHD counterparts [84-88]. In order to address possible bias, several study designs and statistical models have been proposed [89,90]. Among the others, it is worth mentioning the study performed by Kramer and colleagues in 2012, which included 29088 patients from 16 European National or Regional renal registries and used the instrumental variable method to minimize the effect of unmeasured confounders. Standard analysis adjusted for age, sex, primary renal disease, duration of dialysis, donor type, year of transplantation, and country showed that pre-transplant PD was associated with better patient (HR 0.83, 95\% CI 0.76-0.91) and graft (HR 0.90, 95\% CI 0.84-0.96) survivals than ICHD. However, the instrumental variable model revealed that a $10 \%$ increase in the case-mix adjusted center percentage of patients on PD was neither associated with post-transplant recipient survival (HR 1.00, 95\% CI 0.97-1.04) nor with graft failure (HR 1.01, 95\% CI 0.98-1.04) [91].

Overall, current literature demonstrates that pre-transplant PD offers superior or at least equivalent recipient and graft survival rates compared to ICHD [23]. Even though there is evidence that HHD represents a valuable option for many patients with ESRD [49,50,92-94], the lack of information regarding KT outcomes in recipients previously treated with HHD 
does not allow to compare HHD and PD. Due to their methodological limitations, available studies cannot confirm any causality effect between pre-transplant PD and post-transplant outcomes. As a consequence, the exact mechanisms behind the theoretical survival advantage associated with PD remain undetermined. To date, a better RRF at the time of transplant and a reduced incidence of DGF have been recognized as the most plausible contributing factors.

\section{Delayed Graft Function}

Widely accepted definitions of DGF are the need for dialysis during the first week after transplant or a decrease in serum creatinine concentration ( $\mathrm{SCr}$ ) less than $50 \%$ from baseline, by post-operative day three (T1/2 SCr) [95-97]. DGF is a well-recognized risk factor for peri-operative surgical complications, rejection, and premature transplant loss. Furthermore, the occurrence of DGF can be used as a surrogate marker of late transplant outcomes. In particular, it has been demonstrated that the duration of DGF represents an independent predictor of long-term allograft function and survival [98-101].

The impact of pre-transplant RRT on DGF rate and length has been extensively studied. Back in 1996, Perez-Fontan et al. first evaluated the incidence of DGF in patients who had been treated with PD $(n=92)$ or ICHD $(n=587)$ before deceased-donor KT. The proportion of recipients experiencing DGF was $22.5 \%$ in the PD group and $39.5 \%$ in the ICHD group. Remarkably, dialysis modality was the main predisposing factor for DGF [102]. In a case-control study published in 1999, deceased-donor KT recipients previously treated with PD $(n=117)$ or ICHD $(n=117)$ were matched for age, sex, duration of RRT, HLA compatibility, and cold and warm ischemia times. DGF was recorded in $23.1 \% \mathrm{PD}$ and $50.4 \%$ ICHD patients ( $p=0.0001)$ with a mean T1/2 SCr of $5.0 \pm 6.6$ and $9.8 \pm 11.5$ days, respectively $(p<0.0001)$ [103]. Bleyer and colleagues used the United Network of Organ Sharing (UNOS) database to compare early transplant-related outcomes between PD and ICHD patients. They showed that the odds of not producing urine during the first $24 \mathrm{~h}$ after KT were 1.49 (1.28-1.74) times higher in the ICHD group [104]. In the following years, many series and meta-analyses reported results in favor of PD, thus suggesting an association between pre-transplant RRT and DGF [23,29,30,32,33,72,73,82,105]. On the contrary, no significant differences in DGF rates were detected in the studies performed by Caliskan et al. or Dipalma et al. in 2009 and 2016, respectively [31,76].

It has been speculated that the lower incidence of DGF reported among KT recipients previously treated with PD, is actually due to a more favorable peri-operative fluid balance or a better RRF compared to ICHD and HHD, thus reflecting the possibility of indication-related confounders or selection bias [33]. The observation that more than 50\% of the transplant candidates on PD had a pre-operative pulmonary arterial pressure (PAP) exceeding $25 \mathrm{mmHg}$ (mean PAP, $21.1 \mathrm{mmHg}$ ), certainly supported the hypothesis that PD patients could be frequently over-hydrated (or perhaps under-dialyzed) [106]. However, analyzing data from a cohort of first deceased-donor KT recipients, an elegant study from the University Hospital of Gent, demonstrated that pre-transplant PD and optimized (slightly positive) peri-operative fluid balance were independent predictors of immediate graft function [107]. As a matter of fact, recent data indicate that graft function is more likely affected by intra-operative and early post-operative fluid loads rather than by chronic hydration [108,109]. The RRF at the time of transplant may also play a role $[110,111]$ Besides, there is now evidence that over-hydration is associated with adverse outcomes among PD and transplant patients [112].

\section{Residual Renal Function at the Time of Transplant}

Many patients with chronic kidney disease (CKD) experience a progressive loss of glomerular filtration rate (GFR) and urinary output. The latter event may eventually lead to decreased bladder capacity, detrusor over-activity, and impaired bladder emptying [113-117]. It is demonstrated that KT recipients with an atrophic or dysfunctional bladder are at higher risk of prolonged catheterization, urinary leakage, and severe vesi- 
coureteral reflux than those with normal bladder volume and function [116-120]. Importantly, dialysis vintage represents the most relevant predisposing factor for irreversible loss of RRF and atrophic bladder [116,118,120,121].

The first report showing that patients on PD maintain a better RRF than those on ICHD was published in 1983 [122]. Since then, a plethora of studies have confirmed the superiority of PD over ICHD or HHD in RRF preservation, with a relative difference in GFR loss ranging from $20 \%$ to $80 \%$, depending on the series [123-130]. A very recent study has also shown that PD may slow RRF decline compared to the pre-dialysis [110]. PD can favor RRF preservation through multiple mechanisms. In particular, PD ensures less volume and osmotic pressure fluctuations than ICHD or HHD, thus reducing the occurrence of transient hemodynamic instability. This positive effect seems to be associated with a steadier glomerular capillary pressure and a more consistent glomerular filtration. Moreover, the possibility of avoiding rapid changes in circulating volume and osmolality reduces the risk of renal ischemia. The euvolemic or mild hypervolemic status frequently observed during PD could also contribute to RRF preservation [127,130-133].

Before transplant, a better RRF has been associated with improved survival in both PD and ICHD/HHD patients [134-138]. The relative contribution of RRF and peritoneal clearance on patient survival during PD has been investigated [127,131,139-141]. Among the others, the ADEMEX [139] and the NECOSAD-2 [126] studies have shown that there is an $11 \%$ or $12 \%$ reduction in the risk of death per $10 \mathrm{~L}$ per week per $1.73 \mathrm{~m}^{2}$ increment in GFR, without any apparent relationship between survival and PD delivered dose or total small solutes removal. Accordingly, a multivariate logistic regression analysis performed on all Andalusian patients starting PD from 1999 to 2005 ( $n=412)$, has demonstrated that an RRF lower than $4.33 \mathrm{~mL} / \mathrm{min}$ is an independent predictor of death as much as diabetes, CVD, or age [142].

Further benefits arising from RRF preservation are decreased systemic blood pressure $[143,144]$, reduced left ventricular hypertrophy [145-147], increased sodium removal [148-150], improved fluid balance [149,151,152], lower serum b2-microglobulin levels [153-155], better nutritional status [156-158], and lower circulating inflammatory markers [159-162]. Additionally, RRF facilitates the achievement of adequacy targets [126,163-166] and may contribute to controlling serum phosphate, uric acid, bicarbonate, and cholesterol levels $[161,167,168]$. An association between RRF and DGF rate has been established $[112,113]$. However, the fact that most patients receiving PD exhibit preserved urinary output at the time of dialysis initiation does not allow to rule out possible selection bias.

\section{Quality of Life on the Transplant Waiting List}

KT provides better QoL than dialysis $[65,169,170]$. Although the average time spent on the TWL varies among countries, it has been estimated that $5 \%$ to $15 \%$ of the patients remain enlisted long enough to be either removed from the list or die before receiving a suitable organ [52,171,172]. In 2019, among 101000 patients waiting for a KT in the US, more than 8000 died or were suspended due to deteriorating medical conditions, with a median wait-time for a deceased-donor kidney exceeding five years [173]. ESRD and long-term dialysis can affect several aspects of life, negatively impacting physical, psychological, social, or financial wellness. As stated in the campaign "Living Well with Kidney Disease", ensuring an acceptable QoL during RRT represents a fundamental issue for patients and health care providers [174]. To date, the most used tool for the evaluation of the QoL in patients on RRT is the Kidney Disease Quality of Life (KDQOL) questionnaire [175]. Multiple versions have been proposed, such as the KDQOL Short Form (SF) 1.3, the KDQOL SF 36, and the Short Form 12 [176,177]. The Choices for Healthy Outcomes in Caring for End-Stage Renal Disease (CHOICE) Health Experience Questionnaire is frequently adopted to integrate the SF 36 and it can highlight more granular differences between HD and PD [178]. 
Compared to ICHD, PD gives the opportunity to dialyze at home, independently or with the help of a caregiver. Additionally, the short amount of time required for fluid exchange allows a flexible schedule and the opportunity to work, travel or participate in recreational activities [179-181]. Using the KDQOL SF 1.3, Wakeel et al. compared the QoL of 200 patients on ICHD or PD in Saudi Arabia. Those with cognitive impairment, neurological deficits, or psychiatric disorders were excluded. PD was associated with higher scores in almost all the domains of the questionnaire [182]. De Abreu et al. reported higher degrees of satisfaction and better support from the dialysis staff in PD patients compared to ICHD [183]. In a Brazilian study adopting the KDQOL SF 36 to evaluate 222 ICHD and 116 PD patients, the PD group showed higher scores than the ICHD group in domains related to work status ( 25 vs $15, p=0.012$ ), encouragement from the dialysis staff (96 vs 83; $p=0.008$ ), and patient satisfaction ( 82 vs $71 ; p<0.005$ ) [184]. Comparative studies and meta-analyses concluded that PD was associated with less emotional stress $[185,186]$ and a lower odd of cognitive dysfunction [187] than ICHD.

The ability to remain employed after starting RRT is another remarkable aspect of the QoL of dialysis patients [188-190]. In this regard, it has been shown that PD offers higher chances of employment than ICHD or HHD [85,191,192].

\section{Cost of Dialysis before Transplant}

Chronic RRT represents one of the most relevant financial burdens for both public and private healthcare systems worldwide. Current projections suggest that the prevalence of ESRD will further increase in the near future due to the rising incidence of diabetes, hypertension, and obesity as well as the progressive aging of the population [193-196]. It is demonstrated that KT ensures better patient survival and QoL than dialysis, with reduced costs $[171,197,198]$. Nevertheless, the vast majority of KT candidates spend a considerable amount of time on dialysis before being transplanted [173]. Therefore, the cost of RRT for patients on the TWL should not be neglected.

Over the years, there have been multiple studies aiming to compare the costs associated with PD and ICHD. On the contrary, data on HHD are still scarce [92,93,196,199]. Available literature suggests that ICHD is more expensive than PD, at least in more economically developed countries $[200,201]$. Nevertheless, mixed results have been reported analyzing the costs of PD and ICHD in Asia [202-207] or Africa [208-211], likely reflecting the impact of geographical, social, and cultural differences in determining the actual expenses related to chronic RRT. Karopadi et al. [212] assessed the cost of PD and ICHD across the world. The results were reported as the annual per patient cost of ICHD divided by the annual per patient cost of PD (ICHD/PD ratio). Forty-six countries were included. The cost of ICHD was 1.25-2.35 higher than PD in 22 countries (17 more economically developed and 5 under-developed), $0.90-1.25$ times the cost of PD in 15 countries ( 2 more economically developed and 13 under-developed), and 0.22-0.90 times the cost of PD in 9 countries ( 1 more economically developed and 8 under-developed). Overall, these data confirm that, in more economically developed countries, PD is less expensive than ICHD. In less economically developed countries, PD is a financially suitable option provided that an economy of scale is achieved, with local production or low import duties on dialysis equipment [212].

According to the USRDS 2020 Annual Data Report, total inflation-adjusted Medicare expenditures per patient with ESRD rose, between 2009 and 2018, by more than $2 \%$ (from 40.9 to 49.2 USD billion). ICHD remained the most expensive RRT at 93191 USD per person annually, whereas per person per year spending for those receiving a KT or remaining on PD was 37304 and 78741 USD, respectively [10]. It can be argued that such a remarkable difference between ICHD and PD is due to a selection bias, as sicker and, therefore, more costly patients are referred to ICHD. Furthermore, the costs emerging from PD failure and the shift to ICHD should be considered. However, an annual per patient saving of about 15000 USD and reduced costs for patients switching from PD to ICHD compared to those remaining on ICHD have been reported [213,214]. Certainly, it would be relevant 
to evaluate, with properly designed economic health-related studies, the costs of hospital admissions and hospital attendances for vascular accesses vs PD catheters procedures and complications [215].

\section{Conclusions}

Historically, ICHD has been the preferred RRT modality for most ESRD patients awaiting a KT. Over the years, several studies have demonstrated that the perceived advantages of ICHD over PD, in this particular population, are not supported by solid evidence. On the contrary, a critical analysis of the literature seems to suggest that PD may be particularly beneficial for transplant candidates. Demonstrably, patients on the TWL who receive PD have reduced all-cause mortality, improved QoL, and reduced costs compared to those on ICHD. Also, properly delivered PD allows avoiding vascular access placement and fistula-related cardiocirculatory overload. After transplant, recipients who were on PD benefit from lower incidences of DGF and fewer peri-operative urological complications. However, further and properly designed studies are needed to confirm that these encouraging results eventually translate into better long-term graft or recipient survival. More comparative data on HHD is also warranted.

Author Contributions: Conceptualization, L.N., E.F. and A.S.; writing-original draft preparation, L.N.; writing-review and editing, E.F., A.S., R.C. and F.T.; visualization, L.N. and R.C.; supervision, E.F., A.S., P.M., M.G. and G.C.; extensive revision, E.F. and F.T. All authors have read and agreed to the published version of the manuscript.

Funding: This research received no external funding.

Institutional Review Board Statement: Not applicable.

Informed Consent Statement: Not applicable.

Data Availability Statement: Not applicable.

Conflicts of Interest: The authors declare no conflict of interest.

\section{References}

1. Wolfe, R.A.; Ashby, V.B.; Milford, E.L.; Ojo, A.O.; Ettenger, R.E.; Agodoa, L.Y.; Held, P.J.; Port, F.K. Comparison of mortality in all patients on dialysis, patients on dialysis awaiting transplantation, and recipients of a first cadaveric transplant. N. Engl. J. Med. 1999, 341, 1725-1730. [CrossRef] [PubMed]

2. Ojo, A.O.; Hanson, J.A.; Meier-Kriesche, H.U.; Okechukwu, C.N.; Wolfe, R.A.; Leichtman, A.B.; Agodoa, L.Y.; Kaplan, B.; Port, F.K. Survival in recipients of marginal cadaveric donor kidneys compared with other recipients and wait-listed transplant candidates. J. Am. Soc. Nephrol. 2001, 12, 589-597. [CrossRef] [PubMed]

3. Merion, R.M.; Ashby, V.B.; Wolfe, R.A.; Distant, D.A.; Hulbert-Shearon, T.E.; Metzger, R.A.; Ojo, A.O.; Port, F.K. Deceased-donor characteristics and the survival benefit of kidney transplantation. JAMA 2005, 294, 2726-2733. [CrossRef] [PubMed]

4. Zompolas, I.; Peters, R.; Liefeldt, L.; Lehner, L.J.; Budde, K.; Ralla, B.; Goranova, I.; Maxeiner, A.; Lerchbaumer, M.H.; Marticorena Garcia, S.R.; et al. Outcomes of Deceased Donor Kidney Transplantation in the Eurotransplant Senior Program with A Focus on Recipients $\geq 75$ Years. J. Clin. Med. 2021, 10, 5633. [CrossRef]

5. Ghanta, M.; Jim, B. Renal Transplantation in Advanced Chronic Kidney Disease Patients. Med. Clin. N. Am. 2016, 100, 465-476. [CrossRef]

6. Kasiske, B.L.; Snyder, J.J.; Matas, A.J.; Ellison, M.D.; Gill, J.S.; Kausz, A.T. Preemptive kidney transplantation: The advantage and the advantaged. J. Am. Soc. Nephrol. 2002, 13, 1358-1364. [CrossRef]

7. Meier-Kriesche, H.U.; Kaplan, B. Waiting time on dialysis as the strongest modifiable risk factor for renal transplant outcomes: A paired donor kidney analysis. Transplantation 2002, 74, 1377-1381. [CrossRef]

8. Fu, R.; Kim, S.J.; de Oliveira, C.; Coyte, P.C. An instrumental variable approach confirms that the duration of pretransplant dialysis has a negative impact on the survival of kidney transplant recipients and quantifies the risk. Kidney Int. 2019, 96, 450-459. [CrossRef]

9. Naylor, K.L.; Kim, S.J.; Kuwornu, J.P.; Dixon, S.N.; Garg, A.X.; McCallum, M.K.; Knoll, G.A. Pre-transplant maintenance dialysis duration and outcomes after kidney transplantation: A multicenter population-based cohort study. Clin. Transplant. 2021, 12, e14553. [CrossRef] 
10. U.S. Renal Data System. USRDS 2020 Annual Data Report: Epidemiology of Kidney Disease and End-Stage Renal Disease in the United States; National Institutes of Health, National Institute of Diabetes and Digestive and Kidney Diseases: Bethesda, MD, USA, 2020.

11. Kainz, A.; Kammer, M.; Reindl-Schwaighofer, R.; Strohmaier, S.; Petr, V.; Viklicky, O.; Abramowicz, D.; Naik, M.; Mayer, G.; Oberbauer, R. Waiting Time for Second Kidney Transplantation and Mortality. Clin. J. Am. Soc. Nephrol. 2022, 17, 90-97. [CrossRef]

12. Scribner, B.H.; Caner, J.E.; Buri, R.; Quinton, W. The technique of continous hemodialysis. Trans. Am. Soc. Artif. Intern. Organs. 1960, 6, 88-103. [PubMed]

13. Murdeshwar, H.N.; Anjum, F. Hemodialysis. In StatPearls [Internet]; StatPearls Publishing: Treasure Island, FL, USA, 2022.

14. Vidt, D.G.; Somerville, J.; Schultz, R.W. A safe peritoneal access device for repeated peritoneal dialysis. JAMA 1970, 214, 2293-2296. [CrossRef] [PubMed]

15. Sachdeva, B.; Zulfiqar, H.; Aeddula, N.R. Peritoneal Dialysis. In StatPearls [Internet]; StatPearls Publishing: Treasure Island, FL, USA, 2022.

16. Guillou, P.J.; Will, E.J.; Davison, A.M.; Giles, G.R. CAPD-A risk factor in renal transplantation? Br. J. Surg. 1984, 71, 878-880. [CrossRef] [PubMed]

17. Shapira, Z.; Shmueli, D.; Yussim, A.; Boner, G.; Haimovitz, C.; Servadio, C. Kidney transplantation in patients on continuous ambulatory peritoneal dialysis. Proc. Eur. Dial. Transplant. Assoc. Eur. Ren. Assoc. 1985, 21, 932-935.

18. Donnelly, P.K.; Shenton, B.K.; Lennard, T.W.; Proud, G.; Taylor, R.M. CAPD and renal transplantation. Br. J. Surg. 1985, 72, 819-821. [CrossRef]

19. Apel, C.; Hornig, C.; Maddux, F.W.; Ketchersid, T.; Yeung, J.; Guinsburg, A. Informed decision-making in delivery of dialysis: Combining clinical outcomes with sustainability. Clin. Kidney J. 2021, 14 (Suppl. 4), i98-i113. [CrossRef]

20. Passalacqua, J.A.; Wiland, A.M.; Fink, J.C.; Bartlett, S.T.; Evans, D.A.; Keay, S. Increased incidence of postoperative infections associated with peritoneal dialysis in renal transplant recipients. Transplantation 1999, 68, 535-540. [CrossRef]

21. Marshall, M.R. A systematic review of peritoneal dialysis-related peritonitis rates over time from national or regional populationbased registries and databases. Perit. Dial. Int. 2022, 42, 39-47. [CrossRef]

22. Esagian, S.M.; Spinos, D.; Vasilopoulou, A.; Syrigos, N.; Bishawi, M.; Lehrich, R.W.; Middleton, J.P.; Suhocki, P.V.; Pappas, T.N.; Economopoulos, K.P. Influence of peritoneal dialysis catheter type on complications and long-term outcomes: An updated systematic review and meta-analysis. J. Nephrol. 2021, 34, 1973-1987. [CrossRef]

23. Jain, D.; Haddad, D.B.; Goel, N. Choice of dialysis modality prior to kidney transplantation: Does it matter? World J. Nephrol. 2019, 8, 1-10. [CrossRef]

24. Ben-David, E.; Hull, R.; Banerjee, D. Diabetes mellitus in dialysis and renal transplantation. Ther. Adv. Endocrinol. Metab. 2021, 12, 20420188211048663. [CrossRef]

25. Danford, C.J.; Lin, S.C.; Smith, M.P.; Wolf, J.L. Encapsulating peritoneal sclerosis. World J. Gastroenterol. 2018, $24,3101-3111$. [CrossRef] [PubMed]

26. Romagnoli, J.; Pedroso, J.A.; Salerno, M.P.; Favi, E.; Spagnoletti, G.; Citterio, F. Posttransplant encapsulating peritoneal sclerosis, long-term success with everolimus and low-dose CNI: A case report. Transplant. Proc. 2014, 46, 2368-2370. [CrossRef] [PubMed]

27. Ojo, A.O.; Hanson, J.A.; Wolfe, R.A.; Agodoa, L.Y.; Leavey, S.F.; Leichtman, A.; Young, E.W.; Port, F.K. Dialysis modality and the risk of allograft thrombosis in adult renal transplant recipients. Kidney Int. 1999, 55, 1952-1960. [CrossRef] [PubMed]

28. Fuquay, R.; Teitelbaum, I. Transplant outcomes and dialysis modality. Contrib. Nephrol. 2012, 178, 251-257. [CrossRef] [PubMed]

29. Dębska-Ślizień, A.; Bobkowska-Macuk, A.; Bzoma, B.; Moszkowska, G.; Milecka, A.; Zadrożny, D.; Wołyniec, W.; Chamienia, A.; Lichodziejewska-Niemierko, M.; Król, E.; et al. Paired Analysis of Outcomes After Kidney Transplantation in Peritoneal and Hemodialysis Patients. Transplant. Proc. 2018, 50, 1646-1653. [CrossRef] [PubMed]

30. Tang, M.; Li, T.; Liu, H. A Comparison of Transplant Outcomes in Peritoneal and Hemodialysis Patients: A Meta-Analysis. Blood Purif. 2016, 42, 170-176. [CrossRef]

31. Dipalma, T.; Fernández-Ruiz, M.; Praga, M.; Polanco, N.; González, E.; Gutiérrez-Solis, E.; Gutiérrez, E.; Andrés, A. Pre-transplant dialysis modality does not influence short- or long-term outcome in kidney transplant recipients: Analysis of paired kidneys from the same deceased donor. Clin. Transplant. 2016, 30, 1097-1107. [CrossRef]

32. Joachim, E.; Gardezi, A.I.; Chan, M.R.; Shin, J.I.; Astor, B.C.; Waheed, S. Association of Pre-Transplant Dialysis Modality and Post-Transplant Outcomes: A Meta-Analysis. Perit. Dial. Int. 2017, 37, 259-265. [CrossRef] [PubMed]

33. McKane, W.S. Should Nephrologists Promote Peritoneal Dialysis as a Bridge to Transplantation? Perit. Dial. Int. 2017, 37, 247-249. [CrossRef]

34. Ibrahim, A.; Chan, C.T. Managing Kidney Failure with Home Hemodialysis. Clin. J. Am. Soc. Nephrol. 2019, 14, 1268-1273. [CrossRef] [PubMed]

35. Schreiber, M.J., Jr. Changing Landscape for Peritoneal Dialysis: Optimizing Utilization. Semin. Dial. 2017, 30, 149-157. [CrossRef] [PubMed]

36. Blake, P.G. Integrated end-stage renal disease care: The role of peritoneal dialysis. Nephrol. Dial. Transplant. 2001, 16 (Suppl. 5), 61-66. [CrossRef] 
37. Tanaka, M.; Mise, N. Need for evidence on long-term prognosis of PD+HD: A commentary. BMC Nephrol. 2021, 22, 10. [CrossRef]

38. Tennankore, K.K.; Nadeau-Fredette, A.C.; Vinson, A.J. Survival comparisons in home hemodialysis: Understanding the present and looking to the future. Nephrol. Ther. 2021, 17S, S64-S70. [CrossRef] [PubMed]

39. Mitra, S.; Kharbanda, K.; Ebah, L. Home haemodialysis: Providing opportunities to reimagine haemodialysis care. Nephrol. Ther. 2021, 17S, S60-S63. [CrossRef]

40. Lubetzky, M.; Tantisattamo, E.; Molnar, M.Z.; Lentine, K.L.; Basu, A.; Parsons, R.F.; Woodside, K.J.; Pavlakis, M.; Blosser, C.D.; Singh, N.; et al. The failing kidney allograft: A review and recommendations for the care and management of a complex group of patients. Am. J. Transplant. 2021, 21, 2937-2949. [CrossRef]

41. Meng, X.; $\mathrm{Wu}, \mathrm{W} . ; \mathrm{Xu}, \mathrm{S}$.; Cheng, Z. Comparison of outcomes of peritoneal dialysis between patients after failed kidney transplant and transplant-naïve patients: A meta-analysis of observational studies. Ren. Fail. 2021, 43, 698-708. [CrossRef]

42. Melo, A.G.J.T.; Barbosa, G.S.B.; VR Cortes, D.D.P.; Ribeiro, R.G.; Araujo, L.K.; Pereira, B.J.; Abensur, H.; Moysés, R.M.A.; Elias, R.M. Returning to PD after kidney transplant failure is a valuable option. Int. Urol. Nephrol. 2021; ahead of print. [CrossRef]

43. Kochar, G.S.; Langone, A.J. How Should We Manage Renal Transplant Patients with Failed Allografts Who Return to Dialysis? Blood Purif. 2020, 49, 228-231. [CrossRef]

44. Yu, X.; Nakayama, M.; Wu, M.S.; Kim, Y.L.; Mushahar, L.; Szeto, C.C.; Schatell, D.; Finkelstein, F.O.; Quinn, R.R.; Duddington, M. Shared Decision-Making for a Dialysis Modality. Kidney Int. Rep. 2021, 7, 15-27. [CrossRef]

45. Morfín, J.A.; Yang, A.; Wang, E.; Schiller, B. Transitional dialysis care units: A new approach to increase home dialysis modality uptake and patient outcomes. Semin. Dial. 2018, 31, 82-87. [CrossRef] [PubMed]

46. Schreiber, M.J.; Chatoth, D.K.; Salenger, P. Challenges and Opportunities in Expanding Home Hemodialysis for 2025. Adv. Chronic. Kidney Dis. 2021, 28, 129-135. [CrossRef] [PubMed]

47. Semple, D.J.; Sypek, M.; Ullah, S.; Davies, C.; McDonald, S. Mortality After Home Hemodialysis Treatment Failure and Return to In-Center Hemodialysis. Am. J. Kidney Dis. 2022, 79, 15-23.e1. [CrossRef] [PubMed]

48. Marshall, M.R.; Polkinghorne, K.R.; Boudville, N.; McDonald, S.P. Home Versus Facility Dialysis and Mortality in Australia and New Zealand. Am. J. Kidney Dis. 2021, 78, 826-836.e1. [CrossRef]

49. Bitar, W.; Helve, J.; Honkanen, E.; Rauta, V.; Haapio, M.; Finne, P. Similar survival on home hemodialysis and automated peritoneal dialysis: An inception cohort study. Nephrol. Dial. Transplant. 2021, gfab233, ahead of print. [CrossRef]

50. Ethier, I.; Cho, Y.; Hawley, C.; Pascoe, E.M.; Roberts, M.A.; Semple, D.; Nadeau-Fredette, A.C.; Wong, G.; Lim, W.H.; Sypek, M.P.; et al. Multicenter registry analysis comparing survival on home hemodialysis and kidney transplant recipients in Australia and New Zealand. Nephrol. Dial. Transplant. 2021, 36, 1937-1946. [CrossRef]

51. Matsushita, K.; Coresh, J.; Sang, Y.; Chalmers, J.; Fox, C.; Guallar, E.; Jafar, T.; Jassal, S.K.; Landman, G.W.; Muntner, P.; et al. Estimated glomerular filtration rate and albuminuria for prediction of cardiovascular outcomes: A collaborative meta-analysis of individual participant data. Lancet Diabetes Endocrinol. 2015, 3, 514-525. [CrossRef]

52. Wallace, D.; Robb, M.; Hughes, W.; Johnson, R.; Ploeg, R.; Neuberger, J.; Forsythe, J.; Cacciola, R. Outcomes of Patients Suspended From the National Kidney Transplant Waiting List in the United Kingdom Between 2000 and 2010. Transplantation 2020, 104, 1654-1661. [CrossRef]

53. Vonesh, E.F.; Snyder, J.J.; Foley, R.N.; Collins, A.J. The differential impact of risk factors on mortality in hemodialysis and peritoneal dialysis. Kidney Int. 2004, 66, 2389-2401. [CrossRef]

54. Heaf, J.G.; Løkkegaard, H.; Madsen, M. Initial survival advantage of peritoneal dialysis relative to haemodialysis. Nephrol. Dial. Transplant. 2002, 17, 112-117. [CrossRef]

55. Fenton, S.S.; Schaubel, D.E.; Desmeules, M.; Morrison, H.I.; Mao, Y.; Copleston, P.; Jeffery, J.R.; Kjellstrand, C.M. Hemodialysis versus peritoneal dialysis: A comparison of adjusted mortality rates. Am. J. Kidney Dis. 1997, 30, 334-342. [CrossRef]

56. Liem, Y.S.; Wong, J.B.; Hunink, M.G.; de Charro, F.T.; Winkelmayer, W.C. Comparison of hemodialysis and peritoneal dialysis survival in The Netherlands. Kidney Int. 2007, 71, 153-158. [CrossRef] [PubMed]

57. Weinhandl, E.D.; Foley, R.N.; Gilbertson, D.T.; Arneson, T.J.; Snyder, J.J.; Collins, A.J. Propensity-matched mortality comparison of incident hemodialysis and peritoneal dialysis patients. J. Am. Soc. Nephrol. 2010, 21, 499-506. [CrossRef] [PubMed]

58. Mehrotra, R.; Chiu, Y.W.; Kalantar-Zadeh, K.; Bargman, J.; Vonesh, E. Similar outcomes with hemodialysis and peritoneal dialysis in patients with end-stage renal disease. Arch. Intern. Med. 2011, 171, 110-118. [CrossRef]

59. Nadeau-Fredette, A.C.; Hawley, C.M.; Pascoe, E.M.; Chan, C.T.; Clayton, P.A.; Polkinghorne, K.R.; Boudville, N.; Leblanc, M.; Johnson, D.W. An Incident Cohort Study Comparing Survival on Home Hemodialysis and Peritoneal Dialysis (Australia and New Zealand Dialysis and Transplantation Registry). Clin. J. Am. Soc. Nephrol. 2015, 10, 1397-1407. [CrossRef]

60. Annual Data, U.S. Renal Data System. USRDS 2009 Report Atlas of Chronic Kidney Disease and End-Stage Renal Disease in the United States; National Institutes of Health, National Institute of Diabetes and Digestive and Kidney Diseases: Bethesda, MD, USA, 2009.

61. Tchervenkov, J.I.; Cantarovich, M. Is It Time to Make Renal Transplantation Referral Mandatory? Transplantation 2020, 104, 233-234. [CrossRef]

62. Fragale, G.D.; Pujol, G.S.; Laham, G.; Raffaele, P.; Fortunato, M.; Imperiali, N.; Giordani, M.C.; Taylor, M.; Ciappa, J.; Matamala, N.; et al. Renal Transplantation in Patients Older Than 60 Years with High Comorbidity. Is There a Survival Benefit? A Multicenter Study in Argentina. Transplantation 2020, 104, 1746-1751. [CrossRef] 
63. Zhang, Y.; Gerdtham, U.G.; Rydell, H.; Jarl, J. Quantifying the Treatment Effect of Kidney Transplantation Relative to Dialysis on Survival Time: New Results Based on Propensity Score Weighting and Longitudinal Observational Data from Sweden. Int. J. Environ. Res. Public Health 2020, 17, 7318. [CrossRef]

64. Wang, Y.; Snoep, J.D.; Hemmelder, M.H.; van der Bogt, K.E.A.; Bos, W.J.W.; van der Boog, P.J.M.; Dekker, F.W.; de Vries, A.P.J.; Meuleman, Y. Outcomes after kidney transplantation, let's focus on the patients' perspectives. Clin. Kidney J. 2021, 14, 1504-1513. [CrossRef]

65. Wang, Y.; Hemmelder, M.H.; Bos, W.J.W.; Snoep, J.D.; de Vries, A.P.J.; Dekker, F.W.; Meuleman, Y. Mapping health-related quality of life after kidney transplantation by group comparisons: A systematic review. Nephrol. Dial. Transplant. 2021, 36, 2327-2339. [CrossRef]

66. Ponticelli, C.; Favi, E. Physical Inactivity: A Modifiable Risk Factor for Morbidity and Mortality in Kidney Transplantation. J. Pers. Med. 2021, 11, 927. [CrossRef] [PubMed]

67. Kaplan, B.; Meier-Kriesche, H.U. Death after graft loss: An important late study endpoint in kidney transplantation. Am. J. Transplant. 2002, 2, 970-974. [CrossRef] [PubMed]

68. Davis, S.; Mohan, S. Managing Patients with Failing Kidney Allograft: Many Questions Remain. Clin. J. Am. Soc. Nephrol 2021, CJN.14620920, ahead of print. [CrossRef] [PubMed]

69. O'Donoghue, D.; Manos, J.; Pearson, R.; Scott, P.; Bakran, A.; Johnson, R.; Dyer, P.; Martin, S.; Gokal, R. Continuous ambulatory peritoneal dialysis and renal transplantation: A ten-year experience in a single center. Perit. Dial. Int. 1992, 12, 242-249. [CrossRef]

70. Cosio, F.G.; Alamir, A.; Yim, S.; Pesavento, T.E.; Falkenhain, M.E.; Henry, M.L.; Elkhammas, E.A.; Davies, E.A.; Bumgardner, G.L.; Ferguson, R.M. Patient survival after renal transplantation: I. The impact of dialysis pre-transplant. Kidney Int. 1998, 53, 767-772. [CrossRef]

71. Binaut, R.; Hazzan, M.; Pruvot, F.R.; Dracon, M.; Lelièvre, G.; Noël, C. Comparative study of chronic ambulatory peritoneal dialysis versus hemodialysis patients after kidney transplantation: Clinical and financial assessment. Transplant. Proc. 1997, 29, 2428. [CrossRef]

72. Joseph, J.T.; Jindal, R.M. Influence of dialysis on post-transplant events. Clin. Transplant. 2002, 16, 18-23. [CrossRef] [PubMed]

73. Snyder, J.J.; Kasiske, B.L.; Gilbertson, D.T.; Collins, A.J. A comparison of transplant outcomes in peritoneal and hemodialysis patients. Kidney Int. 2002, 62, 1423-1430. [CrossRef] [PubMed]

74. Goldfarb-Rumyantzev, A.S.; Hurdle, J.F.; Scandling, J.D.; Baird, B.C.; Cheung, A.K. The role of pretransplantation renal replacement therapy modality in kidney allograft and recipient survival. Am. J. Kidney Dis. 2005, 46, 537-549. [CrossRef]

75. Yang, Q.; Zhao, S.; Chen, W.; Mao, H.; Huang, F.; Zheng, Z.; Chen, L.; Fei, J.; Yu, X. Influence of dialysis modality on renal transplant complications and outcomes. Clin. Nephrol. 2009, 72, 62-68. [CrossRef]

76. Caliskan, Y.; Yazici, H.; Gorgulu, N.; Yelken, B.; Emre, T.; Turkmen, A.; Yildiz, A.; Aysuna, N.; Bozfakioglu, S.; Sever, M.S. Effect of pre-transplant dialysis modality on kidney transplantation outcome. Perit. Dial. Int. 2009, 29 (Suppl. 2), S117-S122. [CrossRef] [PubMed]

77. Resende, L.; Guerra, J.; Santana, A.; Mil-Homens, C.; Abreu, F.; da Costa, A.G. Influence of dialysis duration and modality on kidney transplant outcomes. Transplant. Proc. 2009, 41, 837-839. [CrossRef] [PubMed]

78. Freitas, C.; Fructuoso, M.; Martins, L.S.; Almeida, M.; Pedroso, S.; Dias, L.; Henriques, A.C.; Cabrita, A. Posttransplant outcomes of peritoneal dialysis versus hemodialysis patients. Transplant. Proc. 2011, 43, 113-116. [CrossRef]

79. Sharma, A.; Teigeler, T.L.; Behnke, M.; Cotterell, A.; Fisher, R.; King, A.; Gehr, T.; Posner, M. The mode of pretransplant dialysis does not affect postrenal transplant outcomes in african americans. J. Transplant. 2012, 2012, 303596. [CrossRef] [PubMed]

80. López-Oliva, M.O.; Rivas, B.; Pérez-Fernández, E.; Ossorio, M.; Ros, S.; Chica, C.; Aguilar, A.; Bajo, M.A.; Escuin, F.; Hidalgo, L.; et al. Pretransplant peritoneal dialysis relative to hemodialysis improves long-term survival of kidney transplant patients: A single-center observational study. Int. Urol. Nephrol. 2014, 46, 825-832. [CrossRef] [PubMed]

81. Schwenger, V.; Döhler, B.; Morath, C.; Zeier, M.; Opelz, G. The role of pretransplant dialysis modality on renal allograft outcome. Nephrol. Dial. Transplant. 2011, 26, 3761-3766. [CrossRef] [PubMed]

82. Molnar, M.Z.; Mehrotra, R.; Duong, U.; Bunnapradist, S.; Lukowsky, L.R.; Krishnan, M.; Kovesdy, C.P.; Kalantar-Zadeh, K. Dialysis modality and outcomes in kidney transplant recipients. Clin. J. Am. Soc. Nephrol. 2012, 7, 332-341. [CrossRef]

83. Lin, H.T.; Liu, F.C.; Lin, J.R.; Pang, S.T.; Yu, H.P. Impact of the pretransplant dialysis modality on kidney transplantation outcomes: A nationwide cohort study. BMJ Open 2018, 8, e020558. [CrossRef]

84. Miskulin, D.C.; Meyer, K.B.; Athienites, N.V.; Martin, A.A.; Terrin, N.; Marsh, J.V.; Fink, N.E.; Coresh, J.; Powe, N.R.; Klag, M.J.; et al. Comorbidity and other factors associated with modality selection in incident dialysis patients: The CHOICE Study. Choices for Healthy Outcomes in Caring for End-Stage Renal Disease. Am. J. Kidney Dis. 2002, 39, 324-336. [CrossRef]

85. Stack, A.G. Determinants of modality selection among incident US dialysis patients: Results from a national study. J. Am. Soc. Nephrol. 2002, 13, 1279-1287. [CrossRef]

86. Wong, B.; Ravani, P.; Oliver, M.J.; Holroyd-Leduc, J.; Venturato, L.; Garg, A.X.; Quinn, R.R. Comparison of Patient Survival Between Hemodialysis and Peritoneal Dialysis Among Patients Eligible for Both Modalities. Am. J. Kidney Dis. 2018, 71, 344-351. [CrossRef] [PubMed] 
87. Pravoverov, L.V.; Zheng, S.; Parikh, R.; Tan, T.C.; Bhalla, N.; Reddy, C.; Mroz, J.; Jonelis, T.Y.; Go, A.S. Trends Associated with Large-scale Expansion of Peritoneal Dialysis Within an Integrated Care Delivery Model. JAMA Intern. Med. 2019, 179, 1537-1542. [CrossRef] [PubMed]

88. Eroglu, E.; Heimbürger, O.; Lindholm, B. Peritoneal dialysis patient selection from a comorbidity perspective. Semin. Dial. 2022, 35, 25-39. [CrossRef] [PubMed]

89. Vonesh, E.F.; Snyder, J.J.; Foley, R.N.; Collins, A.J. Mortality studies comparing peritoneal dialysis and hemodialysis: What do they tell us? Kidney Int. Suppl. 2006, 70, S3-S11. [CrossRef] [PubMed]

90. Lin, E.; Lung, K.I.; Chertow, G.M.; Bhattacharya, J.; Lakdawalla, D. Challenging Assumptions of Outcomes and Costs Comparing Peritoneal and Hemodialysis. Value Health 2021, 24, 1592-1602. [CrossRef]

91. Kramer, A.; Jager, K.J.; Fogarty, D.G.; Ravani, P.; Finne, P.; Pérez-Panadés, J.; Prütz, K.G.; Arias, M.; Heaf, J.G.; Wanner, C.; et al. Association between pre-transplant dialysis modality and patient and graft survival after kidney transplantation. Nephrol. Dial. Transplant. 2012, 27, 4473-4480. [CrossRef]

92. Gupta, N. Strategic Planning for Starting or Expanding a Home Hemodialysis Program. Adv. Chronic. Kidney Dis. 2021, 28, 143-148. [CrossRef]

93. Weinhandl, E.D. Economic Impact of Home Hemodialysis. Adv. Chronic. Kidney Dis. 2021, 28, 136-142. [CrossRef]

94. Budhram, B.; Sinclair, A.; Komenda, P.; Severn, M.; Sood, M.M. A Comparison of Patient-Reported Outcome Measures of Quality of Life By Dialysis Modality in the Treatment of Kidney Failure: A Systematic Review. Can. J. Kidney Health Dis. 2020, 7, 2054358120957431. [CrossRef]

95. Mannon, R.B. Delayed Graft Function: The AKI of Kidney Transplantation. Nephron 2018, 140, 94-98. [CrossRef]

96. Bahl, D.; Haddad, Z.; Datoo, A.; Qazi, Y.A. Delayed graft function in kidney transplantation. Curr. Opin. Organ. Transplant. 2019, 24, 82-86. [CrossRef] [PubMed]

97. Mannon, R.B. Acute Kidney Injury in Kidney Transplants: New Insights. Nephron 2019, 143, 193-196. [CrossRef] [PubMed]

98. Yarlagadda, S.G.; Coca, S.G.; Formica, R.N., Jr.; Poggio, E.D.; Parikh, C.R. Association between delayed graft function and allograft and patient survival: A systematic review and meta-analysis. Nephrol. Dial. Transplant. 2009, 24, 1039-1047. [CrossRef] [PubMed]

99. Zheng, Y.T.; Chen, C.B.; Yuan, X.P.; Wang, C.X. Impact of acute kidney injury in donors on renal graft survival: A systematic review and Meta-Analysis. Ren. Fail. 2018, 40, 649-656. [CrossRef]

100. Favi, E.; James, A.; Puliatti, C.; Whatling, P.; Ferraresso, M.; Rui, C.; Cacciola, R. Utility and safety of early allograft biopsy in adult deceased donor kidney transplant recipients. Clin. Exp. Nephrol. 2020, 24, 356-368. [CrossRef]

101. Palmisano, A.; Gandolfini, I.; Delsante, M.; Cantarelli, C.; Fiaccadori, E.; Cravedi, P.; Maggiore, U. Acute Kidney Injury (AKI) before and after Kidney Transplantation: Causes, Medical Approach, and Implications for the Long-Term Outcomes. J. Clin. Med. 2021, 10, 1484. [CrossRef] [PubMed]

102. Pérez Fontán, M.; Rodríquez-Carmona, A.; Bouza, P.; García Falcón, T.; Moncalián, J.; Oliver, J.; Valdés, F. Outcome of grafts with long-lasting delayed function after renal transplantation. Transplantation 1996, 62, 42-47. [CrossRef]

103. Vanholder, R.; Heering, P.; Loo, A.V.; Biesen, W.V.; Lambert, M.C.; Hesse, U.; Vennet, M.V.; Grabensee, B.; Lameire, N. Reduced incidence of acute renal graft failure in patients treated with peritoneal dialysis compared with hemodialysis. Am. J. Kidney Dis. 1999, 33, 934-940. [CrossRef]

104. Bleyer, A.J.; Burkart, J.M.; Russell, G.B.; Adams, P.L. Dialysis modality and delayed graft function after cadaveric renal transplantation. J. Am. Soc. Nephrol. 1999, 10, 154-159. [CrossRef]

105. Sezer, S.; Karakan, S.; Özdemir Acar, F.N.; Haberal, M. Dialysis as a bridge therapy to renal transplantation: Comparison of graft outcomes according to mode of dialysis treatment. Transplant. Proc. 2011, 43, 485-487. [CrossRef]

106. Issad, B.; Mouquet, C.; Bitker, M.O.; Allouache, M.; Baumelou, A.; Rottembourg, J.; Jacobs, C. Is overhydration in CAPD patients a contraindication to renal transplantation? Adv. Perit. Dial. 1994, 10, 68-72.

107. Van Biesen, W.; Vanholder, R.; Van Loo, A.; Van Der Vennet, M.; Lameire, N. Peritoneal dialysis favorably influences early graft function after renal transplantation compared to hemodialysis. Transplantation 2000, 69, 508-514. [CrossRef] [PubMed]

108. Aulakh, N.K.; Garg, K.; Bose, A.; Aulakh, B.S.; Chahal, H.S.; Aulakh, G.S. Influence of hemodynamics and intra-operative hydration on biochemical outcome of renal transplant recipients. J. Anaesthesiol. Clin. Pharmacol. 2015, 31, 174-179. [CrossRef] [PubMed]

109. Jia, H.; Huang, F.; Zhang, X.; Cheng, J.; Chen, J.; Wu, J. Early perioperative fluid overload is associated with adverse outcomes in deceased donor kidney transplantation. Transpl. Int. 2021, 34, 1862-1874. [CrossRef] [PubMed]

110. Ethier, I.; Cho, Y.; Hawley, C.; Pascoe, E.M.; Viecelli, A.K.; Campbell, S.B.; van Eps, C.; Isbel, N.M.; Cooper, B.A.; Harris, D.C.; et al. Rate of decline in residual kidney function pre and post peritoneal dialysis initiation: A post hoc analysis of the IDEAL study. PLoS ONE 2020, 15, e0242254. [CrossRef]

111. Tang, S.C.W.; Lai, K.N. Peritoneal dialysis: The ideal bridge from conservative therapy to kidney transplant. J. Nephrol. 2020, 33, 1189-1194. [CrossRef] 
112. Shu, Y.; Liu, J.; Zeng, X.; Hong, H.G.; Li, Y.; Zhong, H.; Ma, L.; Fu, P. The Effect of Overhydration on Mortality and Technique Failure Among Peritoneal Dialysis Patients: A Systematic Review and Meta-Analysis. Blood Purif. 2018, 46, 350-358. [CrossRef]

113. Martin, X.; Aboutaieb, R.; Soliman, S.; el Essawy, A.; Dawahra, M.; Lefrancois, N. The use of long-term defunctionalized bladder in renal transplantation: Is it safe? Eur. Urol. 1999, 36, 450-453. [CrossRef]

114. Chen, J.L.; Lee, M.C.; Kuo, H.C. Reduction of cystometric bladder capacity and bladder compliance with time in patients with end-stage renal disease. J. Formos. Med. Assoc. 2012, 111, 209-213. [CrossRef]

115. Song, M.; Park, J.; Kim, Y.H.; Han, D.J.; Song, S.H.; Choo, M.S.; Hong, B. Bladder capacity in kidney transplant patients with end-stage renal disease. Int. Urol. Nephrol. 2015, 47, 101-106. [CrossRef]

116. Hotta, K.; Miura, M.; Wada, Y.; Fukuzawa, N.; Iwami, D.; Sasaki, H.; Seki, T.; Harada, H. Atrophic bladder in long-term dialysis patients increases the risk for urological com-plications after kidney transplantation. Int. J. Urol. 2017, 24, 314-319. [CrossRef] [PubMed]

117. Wicaksono, I.; Rahardjo, H.E. Factors Associated With Postoperative Voiding Dysfunction Post Renal Transplantation. Transplant. Proc. 2020, 52, 3197-3203. [CrossRef] [PubMed]

118. Tillou, X.; Lee-Bion, A.; Hurault de Ligny, B.; Orczyk, C.; Le Gal, S.; Desmonts, A.; Bensadoun, H.; Doerfler, A. Does daily urine output really matter in renal transplantation? Ann. Transplant. 2013, 18, 716-720. [CrossRef] [PubMed]

119. Mitsui, T.; Moriya, K.; Morita, K.; Iwami, D.; Kitta, T.; Kanno, Y.; Takeda, M.; Shinohara, N. Risk Factors for Lower Urinary Tract Dysfunction and Symptoms After Successful Renal Transplantation. Ann. Transplant. 2015, 20, 757-763. [CrossRef] [PubMed]

120. Wilson, R.S.; Courtney, A.E.; Ko, D.S.C.; Maxwell, A.P.; McDaid, J. Long-Term Outcomes of Renal Transplant in Recipients with Lower Urinary Tract Dysfunction. Exp. Clin. Transplant. 2019, 17, 11-17. [CrossRef] [PubMed]

121. Inoue, T.; Satoh, S.; Saito, M.; Numakura, K.; Tsuruta, H.; Obara, T.; Narita, S.; Horikawa, Y.; Tsuchiya, N.; Habuchi, T. Correlations between pretransplant dialysis duration, bladder capacity, and prevalence of vesicoureteral reflux to the graft. Transplantation 2011, 92, 311-315. [CrossRef]

122. Rottembourg, J.; Issad, B.; Gallego, J.L.; Degoulet, P.; Aime, F.; Gueffaf, B.; Legrain, M. Evolution of residual renal function in patients undergoing maintenance haemodialysis or continuous ambulatory peritoneal dialysis. Proc. Eur. Dial. Transplant. Assoc. 1983, 19, 397-403.

123. Moist, L.M.; Port, F.K.; Orzol, S.M.; Young, E.W.; Ostbye, T.; Wolfe, R.A.; Hulbert-Shearon, T.; Jones, C.A.; Bloembergen, W.E. Predictors of loss of residual renal function among new dialysis patients. J. Am. Soc. Nephrol. 2000, 11, 556-564. [CrossRef]

124. Misra, M.; Vonesh, E.; Van Stone, J.C.; Moore, H.L.; Prowant, B.; Nolph, K.D. Effect of cause and time of dropout on the residual GFR: A comparative analysis of the decline of GFR on dialysis. Kidney Int. 2001, 59, 754-763. [CrossRef]

125. Lang, S.M.; Bergner, A.; Töpfer, M.; Schiffl, H. Preservation of residual renal function in dialysis patients: Effects of dialysistechnique-related factors. Perit. Dial. Int. 2001, 21, 52-57. [CrossRef]

126. Termorshuizen, F.; Korevaar, J.C.; Dekker, F.W.; van Manen, J.G.; Boeschoten, E.W.; Krediet, R.T.; NECOSAD Study Group. The relative importance of residual renal function compared with peritoneal clearance for patient survival and quality of life: An analysis of the Netherlands Cooperative Study on the Adequacy of Dialysis (NECOSAD)-2. Am. J. Kidney Dis. 2003, 41, 1293-1302. [CrossRef]

127. Weinhandl, E.D.; Gilbertson, D.T.; Collins, A.J. Mortality, Hospitalization, and Technique Failure in Daily Home Hemodialysis and Matched Peritoneal Dialysis Patients: A Matched Cohort Study. Am. J. Kidney Dis. 2016, 67, 98-110. [CrossRef] [PubMed]

128. Tomori, K.; Okada, H. Home Hemodialysis: Benefits, Risks, and Barriers. Contrib. Nephrol. 2018, 196, 178-183. [CrossRef] [PubMed]

129. Gupta, A.; Zimmerman, D. Complications and challenges of home hemodialysis: A historical review. Semin. Dial. 2021, 34, 269-274. [CrossRef]

130. Li, T.; Wilcox, C.S.; Lipkowitz, M.S.; Gordon-Cappitelli, J.; Dragoi, S. Rationale and Strategies for Preserving Residual Kidney Function in Dialysis Patients. Am. J. Nephrol. 2019, 50, 411-421. [CrossRef]

131. Liu, X.; Dai, C. Advances in Understanding and Management of Residual Renal Function in Patients with Chronic Kidney Disease. Kidney Dis. 2017, 2, 187-196. [CrossRef]

132. Krediet, R.T.; Abrahams, A.C.; de Fijter, C.W.H.; Betjes, M.G.H.; Boer, W.H.; van Jaarsveld, B.C.; Konings, C.J.A.M.; Dekker, F.W. The truth on current peritoneal dialysis: State of the art. Neth. J. Med. 2017, 75, 179-189.

133. Blake, P.G.; Dong, J.; Davies, S.J. Incremental peritoneal dialysis. Perit. Dial. Int. 2020, 40, 320-326. [CrossRef]

134. Pérez Fontán, M.; Remón Rodríguez, C.; da Cunha Naveira, M.; Borràs Sans, M.; Rodríguez Suárez, C.; Quirós Ganga, P.; Sánchez Alvarez, E.; Rodríguez-Carmona, A. Baseline Residual Kidney Function and Its Ensuing Rate of Decline Interact to Predict Mortality of Peritoneal Dialysis Patients. PLoS ONE 2016, 11, e0158696. [CrossRef]

135. Shafi, T.; Mullangi, S.; Toth-Manikowski, S.M.; Hwang, S.; Michels, W.M. Residual Kidney Function: Implications in the Era of Personalized Medicine. Semin Dial. 2017, 30, 241-245. [CrossRef]

136. Trinh, E.; Chan, C.T.; Perl, J. Dialysis modality and survival: Done to death. Semin. Dial. 2018, 31, 315-324. [CrossRef] [PubMed]

137. Kong, J.; Davies, M.; Mount, P. The importance of residual kidney function in haemodialysis patients. Nephrology 2018, 23, 1073-1080. [CrossRef] [PubMed] 
138. Toth-Manikowski, S.M.; Sirich, T.L.; Meyer, T.W.; Hostetter, T.H.; Hwang, S.; Plummer, N.S.; Hai, X.; Coresh, J.; Powe, N.R.; Shafi, T. Contribution of 'clinically negligible' residual kidney function to clearance of uremic solutes. Nephrol. Dial. Transplant. 2020, 35, 846-853. [CrossRef] [PubMed]

139. Paniagua, R.; Amato, D.; Vonesh, E.; Correa-Rotter, R.; Ramos, A.; Moran, J.; Mujais, S. Effects of increased peritoneal clearances on mortality rates in peritoneal dialysis: ADEMEX, a prospective, randomized, controlled trial. J. Am. Soc. Nephrol. 2002, 13, 1307-1320. [CrossRef] [PubMed]

140. Tang, Y.; Zhong, H.; Diao, Y.; Qin, M.; Zhou, X. Peritoneal transport rate, systemic inflammation, and residual renal function determine peritoneal protein clearance in continuous ambulatory peritoneal dialysis patients. Int. Urol. Nephrol. 2014, 46, 2215-2219. [CrossRef] [PubMed]

141. Yu, Z.; Lambie, M.; Chess, J.; Williams, A.; Do, J.Y.; Topley, N.; Davies, S.J. Peritoneal Protein Clearance Is a Function of Local Inflammation and Membrane Area Whereas Systemic Inflammation and Comorbidity Predict Survival of Incident Peritoneal Dialysis Patients. Front. Physiol. 2019, 10, 105. [CrossRef] [PubMed]

142. Marrón, B.; Remón, C.; Pérez-Fontán, M.; Quirós, P.; Ortíz, A. Benefits of preserving residual renal function in peritoneal dialysis. Kidney Int. Suppl. 2008, 73, S42-S51. [CrossRef]

143. Menon, M.K.; Naimark, D.M.; Bargman, J.M.; Vas, S.I.; Oreopoulos, D.G. Long-term blood pressure control in a cohort of peritoneal dialysis patients and its association with residual renal function. Nephrol. Dial. Transplant. 2001, 16, $2207-2213$. [CrossRef]

144. Kuroki, Y.; Hori, K.; Tsuruya, K.; Matsuo, D.; Mitsuiki, K.; Hirakata, H.; Nakano, T.; Kitazono, T. Association of blood pressure after peritoneal dialysis initiation with the decline rate of residual kidney function in newly-initiated peritoneal dialysis patients. PLoS ONE 2021, 16, e0254169. [CrossRef]

145. Wang, A.Y.; Wang, M.; Woo, J.; Law, M.C.; Chow, K.M.; Li, P.K.; Lui, S.F.; Sanderson, J.E. A novel association between residual renal function and left ventricular hypertrophy in peritoneal dialysis patients. Kidney Int. 2002, 62, 639-647. [CrossRef]

146. Tomura, M.; Hamasaki, Y.; Komaru, Y.; Miyamoto, Y.; Matsuura, R.; Matsumoto, A.; Doi, K.; Kume, H.; Nangaku, M. Prognostic significance of concentric left ventricular hypertrophy at peritoneal dialysis initiation. BMC Nephrol. 2021, 22, 135. [CrossRef] [PubMed]

147. Tangwonglert, T.; Davenport, A. Changes in extracellular water and left ventricular mass in peritoneal dialysis patients. Kidney Res. Clin. Pract. 2021, 40, 135-142. [CrossRef] [PubMed]

148. Ateş, K.; Nergizoğlu, G.; Keven, K.; Sen, A.; Kutlay, S.; Ertürk, S.; Duman, N.; Karatan, O.; Ertuğ, A.E. Effect of fluid and sodium removal on mortality in peritoneal dialysis patients. Kidney Int. 2001, 60, 767-776. [CrossRef] [PubMed]

149. Mok, N.M.; Fan, N.; Finney, H.; Fan, S.L. Relationship between sodium removal, hydration and outcomes in peritoneal dialysis patients. Nephrology 2021, 26, 676-683. [CrossRef]

150. Kocyigit, H.; Koyuncu, S.; Kocyigit, I.; Karabiyik, U.; Zararsiz, G.; Eroglu, E.; Gundogdu, A.; Sipahioglu, M.H.; Oymak, O.; Tokgoz, B. The effect of sodium exchange and dialytic biochemical parameters on blood pressure, arterial stiffness, and endothelial functions in patients with peritoneal dialysis. Int. Urol. Nephrol. 2020, 52, 2197-2203. [CrossRef]

151. Konings, C.J.; Kooman, J.P.; Schonck, M.; Struijk, D.G.; Gladziwa, U.; Hoorntje, S.J.; van der Wall Bake, A.W.; van der Sande, F.M.; Leunissen, K.M. Fluid status in CAPD patients is related to peritoneal transport and residual renal function: Evidence from a longitudinal study. Nephrol. Dial. Transplant. 2003, 18, 797-803. [CrossRef]

152. Malho Guedes, A.; Marques, R.; Domingos, A.T.; Silva, A.P.; Bernardo, I.; Neves, P.L.; Rodrigues, A.; Krediet, R.T. Overhydration May Be the Missing Link between Peritoneal Protein Clearance and Mortality. Nephron 2021, 145, 474-480. [CrossRef]

153. Montenegro, J.; Martínez, I.; Saracho, R.; González, R. Beta 2 microglobulin in CAPD. Adv. Perit. Dial. 1992, 8, 369-372.

154. Dervisoglu, E.; Anik, Y.; Erdogan, S.; Akansel, G.; Yilmaz, A. Beta2-microglobulin amyloidosis in hemodialysis and peritoneal dialysis patients. Ther. Apher. Dial. 2008, 12, 306-310. [CrossRef]

155. Kong, J.H.; Davies, M.R.P.; Mount, P.F. Relationship between residual kidney function and symptom burden in haemodialysis patients. Int. Med. J. 2021, 51, 52-61. [CrossRef]

156. Szeto, C.C.; Lai, K.N.; Wong, T.Y.; Law, M.C.; Leung, C.B.; Yu, A.W.; Li, P.K. Independent effects of residual renal function and dialysis adequacy on nutritional status and patient outcome in continuous ambulatory peritoneal dialysis. Am. J. Kidney Dis. 1999, 34, 1056-1064. [CrossRef]

157. Huang, L.L.; Mah, J.Y.; Howard, J.; Roberts, M.A.; McMahon, L.P. Incremental peritoneal dialysis is a safe and feasible prescription in incident patients with preserved residual kidney function. Nephrology 2022, 27, 74-81. [CrossRef] [PubMed]

158. Wang, A.Y.; Sea, M.M.; Ip, R.; Law, M.C.; Chow, K.M.; Lui, S.F.; Li, P.K.; Woo, J. Independent effects of residual renal function and dialysis adequacy on actual dietary protein, calorie, and other nutrient intake in patients on continuous ambulatory peritoneal dialysis. J. Am. Soc. Nephrol. 2001, 12, 2450-2457. [CrossRef] [PubMed]

159. Pecoits-Filho, R.; Heimbürger, O.; Bárány, P.; Suliman, M.; Fehrman-Ekholm, I.; Lindholm, B.; Stenvinkel, P. Associations between circulating inflammatory markers and residual renal function in CRF patients. Am. J. Kidney Dis. 2003, 41, 1212-1218. [CrossRef]

160. Raikou, V.D.; Kardalinos, V.; Kyriaki, D. The Relationship of Residual Renal Function with Cardiovascular Morbidity in Hemodialysis Patients and the Potential Role of Monocyte Chemoattractant Protein-1. Kidney Dis. 2018, 4, 20-28. [CrossRef] [PubMed] 
161. Zhou, W.; Hu, W.; Han, G.; Wang, H.; Zhang, J.; Mei, C. The impact of residual renal function on quality of life in patients with peritoneal dialysis. Clin. Nephrol. 2018, 90, 106-111. [CrossRef] [PubMed]

162. De Sequera, P.; Corchete, E.; Bohorquez, L.; Albalate, M.; Perez-Garcia, R.; Alique, M.; Marques, M.; García-Menéndez, E.; Portolés, J.; Ramirez, R. Residual Renal Function in Hemodialysis and Inflammation. Ther. Apher. Dial. 2017, 21, 592-598. [CrossRef] [PubMed]

163. Bargman, J.M.; Thorpe, K.E.; Churchill, D.N. Relative contribution of residual renal function and peritoneal clearance to adequacy of dialysis: A reanalysis of the CANUSA study. J. Am. Soc. Nephrol. 2001, 12, 2158-2162. [CrossRef]

164. Guest, S.; Akonur, A.; Ghaffari, A.; Sloand, J.; Leypoldt, J.K. Intermittent peritoneal dialysis: Urea kinetic modeling and implications of residual kidney function. Perit. Dial. Int. 2012, 32, 142-148. [CrossRef]

165. Lee, M.J.; Park, J.T.; Park, K.S.; Kwon, Y.E.; Oh, H.J.; Yoo, T.H.; Kim, Y.L.; Kim, Y.S.; Yang, C.W.; Kim, N.H.; et al. Prognostic Value of Residual Urine Volume, GFR by 24-hour Urine Collection, and eGFR in Patients Receiving Dialysis. Clin. J. Am. Soc. Nephrol. 2017, 12, 426-434. [CrossRef]

166. Torreggiani, M.; Fois, A.; Njandjo, L.; Longhitano, E.; Chatrenet, A.; Esposito, C.; Fessi, H.; Piccoli, G.B. Toward an individualized determination of dialysis adequacy: A narrative review with special emphasis on incremental hemodialysis. Expert Rev. Mol. Diagn. 2021, 21, 1119-1137. [CrossRef] [PubMed]

167. Wang, A.Y.; Woo, J.; Wang, M.; Sea, M.M.; Sanderson, J.E.; Lui, S.F.; Li, P.K. Important differentiation of factors that predict outcome in peritoneal dialysis patients with different degrees of residual renal function. Nephrol. Dial. Transplant. 2005, 20, 396-403. [CrossRef] [PubMed]

168. Pagé, D.E.; Knoll, G.A.; Cheung, V. The relationship between residual renal function, protein catabolic rate, and phosphate and magnesium levels in peritoneal dialysis patients. Adv. Perit. Dial. 2002, 18, 189-191. [PubMed]

169. Purnell, T.S.; Auguste, P.; Crews, D.C.; Lamprea-Montealegre, J.; Olufade, T.; Greer, R.; Ephraim, P.; Sheu, J.; Kostecki, D.; Powe, N.R.; et al. Comparison of life participation activities among adults treated by hemodialysis, peritoneal dialysis, and kidney transplantation: A systematic review. Am. J. Kidney Dis. 2013, 62, 953-973. [CrossRef] [PubMed]

170. Czyżewski, L.; Sańko-Resmer, J.; Wyzgał, J.; Kurowski, A. Assessment of health-related quality of life of patients after kidney transplantation in comparison with hemodialysis and peritoneal dialysis. Ann. Transplant. 2014, 19, 576-585. [CrossRef] [PubMed]

171. Lentine, K.L.; Pastan, S.; Mohan, S.; Reese, P.P.; Leichtman, A.; Delmonico, F.L.; Danovitch, G.M.; Larsen, C.P.; Harshman, L.; Wiseman, A.; et al. A Roadmap for Innovation to Advance Transplant Access and Outcomes: A Position Statement From the National Kidney Foundation. Am. J. Kidney Dis. 2021, 78, 319-332. [CrossRef]

172. Assfalg, V.; Hüser, N. Repeated kidney re-transplantation in times of organ shortage-A critical review. Curr. Opin. Organ. Transplant. 2021, 26, 106-111. [CrossRef]

173. Hart, A.; Lentine, K.L.; Smith, J.M.; Miller, J.M.; Skeans, M.A.; Prentice, M.; Robinson, A.; Foutz, J.; Booker, S.E.; Israni, A.K.; et al. OPTN/SRTR 2019 Annual Data Report: Kidney. Am. J. Transplant. 2021, 21 (Suppl. 2), 21-137. [CrossRef]

174. World Kidney Day. Available online: https:/ / www.worldkidneyday.org (accessed on 19 January 2022).

175. Hays, R.D.; Kallich, J.D.; Mapes, D.L.; Coons, S.J.; Carter, W.B. Development of the kidney disease quality of life (KDQOL) instrument. Qual. Life Res. 1994, 3, 329-338. [CrossRef]

176. Korevaar, J.C.; Merkus, M.P.; Jansen, M.A.; Dekker, F.W.; Boeschoten, E.W.; Krediet, R.T.; NECOSAD-Study Group. Validation of the KDQOL-SF: A dialysis-targeted health measure. Qual. Life Res. 2002, 11, 437-447. [CrossRef]

177. Lacson, E., Jr.; Xu, J.; Lin, S.F.; Dean, S.G.; Lazarus, J.M.; Hakim, R.M. A comparison of SF-36 and SF-12 composite scores and subsequent hospitalization and mortality risks in long-term dialysis patients. Clin. J. Am. Soc. Nephrol. 2010, 5, 252-260. [CrossRef] [PubMed]

178. Wu, A.W.; Fink, N.E.; Cagney, K.A.; Bass, E.B.; Rubin, H.R.; Meyer, K.B.; Sadler, J.H.; Powe, N.R. Developing a health-related quality-of-life measure for end-stage renal disease: The CHOICE Health Experience Questionnaire. Am. J. Kidney Dis. 2001, 37, 11-21. [CrossRef] [PubMed]

179. Hakeem Ismael, N.; Omer Rashid, A. Health-Related Quality of Life in End-Stage Renal Disease Patients and Healthy Individuals. Galen Med. J. 2020, 9, e1987. [CrossRef] [PubMed]

180. Manera, K.E.; Ju, A.; Baumgart, A.; Hannan, E.; Qiao, W.; Howell, M.; Nataatmadja, M.; Wilkie, M.; Loud, F.; Schwartz, D.; et al. Patient-reported outcome measures for life participation in peritoneal dialysis: A systematic review. Nephrol Dial. Transplant. 2021, 36, 890-901. [CrossRef] [PubMed]

181. Raoofi, S.; Pashazadeh Kan, F.; Rafiei, S.; Hoseinipalangi, Z.; Rezaei, S.; Ahmadi, S.; Masoumi, M.; Noorani Mejareh, Z.; Roohravan Benis, M.; Sharifi, A.; et al. Hemodialysis and peritoneal dialysis-health-related quality of life: Systematic review plus meta-analysis. BMJ Support. Palliat Care 2021. ahead of print. [CrossRef]

182. Al Wakeel, J.; Al Harbi, A.; Bayoumi, M.; Al-Suwaida, K.; Al Ghonaim, M.; Mishkiry, A. Quality of life in hemodialysis and peritoneal dialysis patients in Saudi Arabia. Ann. Saudi. Med. 2012, 32, 570-574. [CrossRef]

183. De Abreu, M.M.; Walker, D.R.; Sesso, R.C.; Ferraz, M.B. Health-related quality of life of patients receiving hemodialysis and peritoneal dialysis in São Paulo, Brazil: A longitudinal study. Value Health 2011, 14 (Suppl. 1), S119-S121. [CrossRef]

184. Gonçalves, F.A.; Dalosso, I.F.; Borba, J.M.; Bucaneve, J.; Valerio, N.M.; Okamoto, C.T.; Bucharles, S.G. Quality of life in chronic renal patients on hemodialysis or peritoneal dialysis: A comparative study in a referral service of Curitiba-PR. J. Bras. Nefrol. 2015, 37, 467-474. [CrossRef] 
185. Griva, K.; Kang, A.W.; Yu, Z.L.; Mooppil, N.K.; Foo, M.; Chan, C.M.; Newman, S.P. Quality of life and emotional distress between patients on peritoneal dialysis versus community-based hemodialysis. Qual. Life Res. 2014, 23, 57-66. [CrossRef]

186. Chuasuwan, A.; Pooripussarakul, S.; Thakkinstian, A.; Ingsathit, A.; Pattanaprateep, O. Comparisons of quality of life between patients underwent peritoneal dialysis and hemodialysis: A systematic review and meta-analysis. Health Qual. Life Outcomes 2020, 18, 191. [CrossRef]

187. Ali, H.; Soliman, K.; Mohamed, M.M.; Daoud, A.; Shafiq, T.; Fülöp, T.; Baharani, J. The effects of dialysis modality choice on cognitive functions in patients with end-stage renal failure: A systematic review and meta-analysis. Int. Urol. Nephrol. 2021, 53, 155-163. [CrossRef]

188. Hallab, A.; Wish, J.B. Employment among Patients on Dialysis: An Unfulfilled Promise. Clin. J. Am. Soc. Nephrol. 2018, 13, 203-204. [CrossRef] [PubMed]

189. Rajkumar, R.; Baumgart, A.; Martin, A.; Tong, A.; Evangelidis, N.; Manera, K.E.; Cho, Y.; Johnson, D.W.; Viecelli, A.; Shen, J.; et al. SONG-HD and SONG-PD initiatives for the SONG-HD and SONG-PD initiatives. Perspectives on ability to work from patients' receiving dialysis and caregivers: Analysis of data from the global SONG initiative. J. Nephrol. 2021. ahead of print. [CrossRef] [PubMed]

190. De Jong, R.W.; Boezeman, E.J.; Chesnaye, N.C.; Bemelman, F.J.; Massy, Z.A.; Jager, K.J.; Stel, V.S.; de Boer, A.G.E.M. Work status and work ability of patients receiving kidney replacement therapy: Results from a European survey. Nephrol. Dial. Transplant. 2021, gfab300, ahead of print. [CrossRef] [PubMed]

191. Kutner, N.G.; Zhang, R.; Huang, Y.; Johansen, K.L. Depressed mood, usual activity level, and continued employment after starting dialysis. Clin. J. Am. Soc. Nephrol. 2010, 5, 2040-2045. [CrossRef] [PubMed]

192. Muehrer, R.J.; Schatell, D.; Witten, B.; Gangnon, R.; Becker, B.N.; Hofmann, R.M. Factors affecting employment at initiation of dialysis. Clin. J. Am. Soc. Nephrol. 2011, 6, 489-496. [CrossRef] [PubMed]

193. Jha, V.; Garcia-Garcia, G.; Iseki, K.; Li, Z.; Naicker, S.; Plattner, B.; Saran, R.; Wang, A.Y.; Yang, C.W. Chronic kidney disease: Global dimension and perspectives. Lancet 2013, 382, 260-272. [CrossRef]

194. Li, P.K.; Ma, T.K. Global impact of nephropathies. Nephrology 2017, 22 (Suppl. 4), 9-13. [CrossRef] [PubMed]

195. Carney, E.F. The impact of chronic kidney disease on global health. Nat. Rev. Nephrol. 2020, 16, 251. [CrossRef]

196. Thurlow, J.S.; Joshi, M.; Yan, G.; Norris, K.C.; Agodoa, L.Y.; Yuan, C.M.; Nee, R. Global Epidemiology of End-Stage Kidney Disease and Disparities in Kidney Replacement Therapy. Am. J. Nephrol. 2021, 52, 98-107. [CrossRef]

197. Axelrod, D.A.; Schnitzler, M.A.; Xiao, H.; Irish, W.; Tuttle-Newhall, E.; Chang, S.H.; Kasiske, B.L.; Alhamad, T.; Lentine, K.L. An economic assessment of contemporary kidney transplant practice. Am. J. Transplant. 2018, 18, 1168-1176. [CrossRef] [PubMed]

198. Fu, R.; Sekercioglu, N.; Berta, W.; Coyte, P.C. Cost-effectiveness of Deceased-donor Renal Transplant Versus Dialysis to Treat End-stage Renal Disease: A Systematic Review. Transplant. Direct. 2020, 6, e522. [CrossRef] [PubMed]

199. Bieber, S.D.; Young, B.A. Home Hemodialysis: Core Curriculum 2021. Am. J. Kidney Dis. 2021, 78, 876-885. [CrossRef] [PubMed]

200. Just, P.M.; Riella, M.C.; Tschosik, E.A.; Noe, L.L.; Bhattacharyya, S.K.; de Charro, F. Economic evaluations of dialysis treatment modalities. Health Policy. 2008, 86, 163-180. [CrossRef]

201. Pike, E.; Hamidi, V.; Ringerike, T.; Wisloff, T.; Klemp, M. More Use of Peritoneal Dialysis Gives Significant Savings: A Systematic Review and Health Economic Decision Model. J. Clin. Med. Res. 2017, 9, 104-116. [CrossRef]

202. Li, P.K.; Chow, K.M. The cost barrier to peritoneal dialysis in the developing world-an Asian perspective. Perit. Dial. Int. 2001, 21 (Suppl. 3), S307-S313. [CrossRef]

203. Kwong, V.W.; Li, P.K. Peritoneal Dialysis in Asia. Kidney Dis. 2015, 1, 147-156. [CrossRef]

204. Nakamoto, H. The Current Status and Future of Peritoneal Dialysis in Japan. Contrib. Nephrol. 2019, 198, 78-86. [CrossRef]

205. Wilkie, M.; Davies, S. Insights on Peritoneal Dialysis in China. Perit. Dial. Int. 2018, 38 (Suppl. 2), S16-S18. [CrossRef]

206. Divyaveer, S.S.; Ramachandran, R.; Sahay, M.; Singh Shah, D.; Akhtar, F.; Bello, A.K.; Iyengar, A.; Johnson, D.W.; Harris, D.C.H.; Levin, A.; et al. International Society of Nephrology Global Kidney Health Atlas: Structures, organization, and services for the management of kidney failure in South Asia. Kidney Int. Suppl. 2021, 11, e97-e105. [CrossRef]

207. Zhang, L.; Wang, J.; Yang, C.W.; Tang, S.C.; Kashihara, N.; Kim, Y.S.; Togtokh, A.; Saad, S.; Ye, F.; Khan, M.; et al. International Society of Nephrology Global Kidney Health Atlas: Structures, organization and services for the management of kidney failure in North and East Asia. Kidney Int. Suppl. 2021, 11, e77-e85. [CrossRef] [PubMed]

208. Abu-Aisha, H.; Elamin, S. Peritoneal dialysis in Africa. Perit. Dial. Int. 2010, 30, 23-28. [CrossRef] [PubMed]

209. Swanepoel, C.R.; Wearne, N.; Okpechi, I.G. Nephrology in Africa-not yet uhuru. Nat. Rev. Nephrol. 2013, 9, 610-622. [CrossRef] [PubMed]

210. Wearne, N.; Kilonzo, K.; Effa, E.; Davidson, B.; Nourse, P.; Ekrikpo, U.; Okpechi, I.G. Continuous ambulatory peritoneal dialysis: Perspectives on patient selection in low- to middle-income countries. Int. J. Nephrol. Renovasc. Dis. 2017, 10, 1-9. [CrossRef] [PubMed]

211. Okpechi, I.G.; Ekrikpo, U.; Moloi, M.W.; Noubiap, J.J.; Okpechi-Samuel, U.S.; Bello, A.K. Prevalence of peritonitis and mortality in patients with ESKD treated with chronic peritoneal dialysis in Africa: A systematic review. BMJ Open 2020, 10, e039970. [CrossRef] [PubMed]

212. Karopadi, A.N.; Mason, G.; Rettore, E.; Ronco, C. Cost of peritoneal dialysis and haemodialysis across the world. Nephrol. Dial. Transplant. 2013, 28, 2553-2569. [CrossRef] 
213. Neil, N.; Guest, S.; Wong, L.; Inglese, G.; Bhattacharyya, S.K.; Gehr, T.; Walker, D.R.; Golper, T. The financial implications for Medicare of greater use of peritoneal dialysis. Clin. Ther. 2009, 31, 880-888. [CrossRef]

214. Chui, B.K.; Manns, B.; Pannu, N.; Dong, J.; Wiebe, N.; Jindal, K.; Klarenbach, S.W. Health care costs of peritoneal dialysis technique failure and dialysis modality switching. Am. J. Kidney Dis. 2013, 61, 104-111. [CrossRef]

215. Maierean, S.M.; Oliver, M.J. Health Outcomes and Cost Considerations of Assisted Peritoneal Dialysis: A Narrative Review. Blood Purif. 2021, 50, 662-666. [CrossRef] 